\title{
Symptomatic accessory lobe of liver with a review of the literature
}

\author{
B. D. Pujari \\ M.S., F.I.C.S.*
}

\author{
S. G. DeOdhaRe \\ M.D., F.C.P.S.
}

Shree Hospital, Extension Area and Miraj Medical College and Wanless Hospital, Miraj, 416410 India

\section{Summary}

An accessory lobe of the liver with long well defined mesentery presenting as recurrent pain in abdomen in a Hindu female is described. This is the seventh case recorded in English literature. The embryological genesis of this anomaly and the possibility of preoperative diagnosis by various techniques is discussed.

ANOMALIES of the liver are rare. Variations in the size and configuration of both lobes are common. Accessory lobes are extremely rare and may be found incidently during an operation or a post-mortem examination. They usually present as small tonguelike projections from the surface of the liver in the vicinity of the gall bladder fossa or, very rarely, as isolated lobes either connected to the liver by a pedicle or having a separate mesentery containing blood vessels and bile ducts.

So far, six cases of pedunculated accessory lobes of the liver with symptoms have been described in English literature and all were in women. This is the seventh case.

\section{Case report}

A 32-year-old Hindu married woman had a 4-year history of repeated attacks of epigastric pain, dragging sensation in the back and nausea. The duration of the attacks varied from a few minutes to a few hours. She had recently (3 weeks) had a comparatively severe attack.

She had been investigated for cholecystitis and duodenal ulcer and the plain X-ray of the abdomen, oral cholecystogram and barium meal studies had been normal. An exploratory laparatomy revealed an accessory lobe of the liver, attached by a well defined triangular mesentery to the gastro-hepatic ligament (Fig. 1). Compared to the rest of the liver, it was darker and multiple bands were seen on its surface. It was freely mobile and could be twisted. Branches from the common hepatic artery and the portal vein traversed along the inferior border of the mesentery, and the bile duct and the hepatic vein ran

Correspondence: Dr B. D. Pujari, Shree Hospital, Extension Area, Miraj 416 410, India. along its superior border. The accessory lobe was $\overrightarrow{\vec{\omega}}$ excised. The patient has had no symptoms for the last year.

The excised lobe was reddish brown and measured $\overline{3}$. $5 \times 4 \times 2 \mathrm{~cm}$ (Fig. 2). The cut surface had the appearance of normal liver. Microscopically, itos showed normal architecture. Kupffer cells containedo haemosiderin pigment. There were foci of periportali round cell infiltration. The hilum showed proliferat- $\rightarrow$ ing bile ducts, dilated lymphatics, blood vessels and? increased fibrous tissue (Fig. 3).

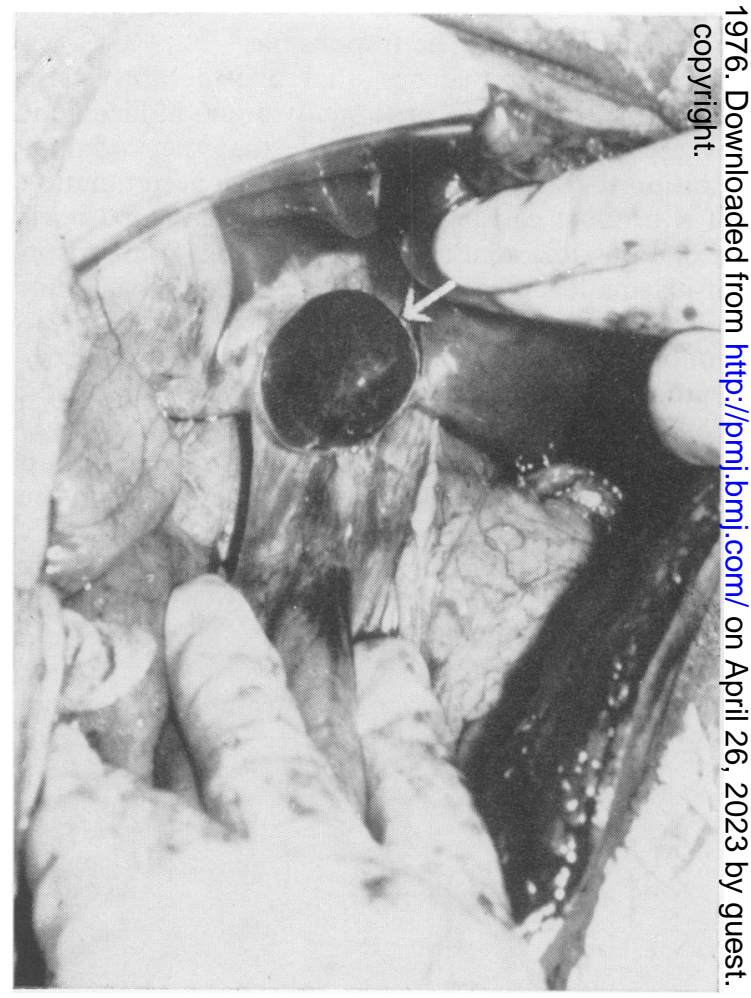

Fig. 1. The congested accessory lobe, attached by a mesentery to the gastrohepatic ligament, is indicated by an arrow. 


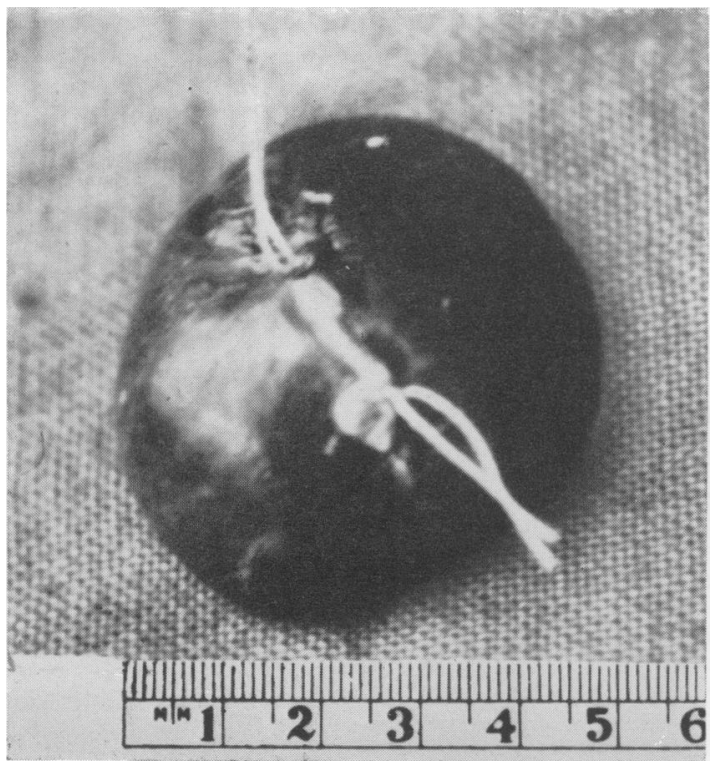

FIG. 2. The excised accessory lobe.

\section{Discussion}

There was circumstantial evidence to suggest torsion of the lobe as described by Llorente and Dardik (1971). In this case, there was a well defined, twistable mesentery, darker in colour, with fibrous bands over its surface, haemosiderin pigment in Kupffer cells, increased fibrous tissue and congested vessels in the hilum which suggest that symptoms were due to repeated torsion of the lobe. In addition, the patient has been asymptomatic for the last year. In this way the present case differs from the reported cases where exploration was done during acute episode and the torsion of the accessory lobe was seen at operation (Cullen, 1925; Lottee and Madier,
1960; Watson and Lee, 1964; Levi, Creque and Cinque, 1969).

The exact origin of the accessory lobe of the liver in man is still unknown. The accessory liver tissue could be formed by the displacement of the primitive rudiment of the organ (McGregor, 1950), or by persistence of the mesodermal septa during proliferation

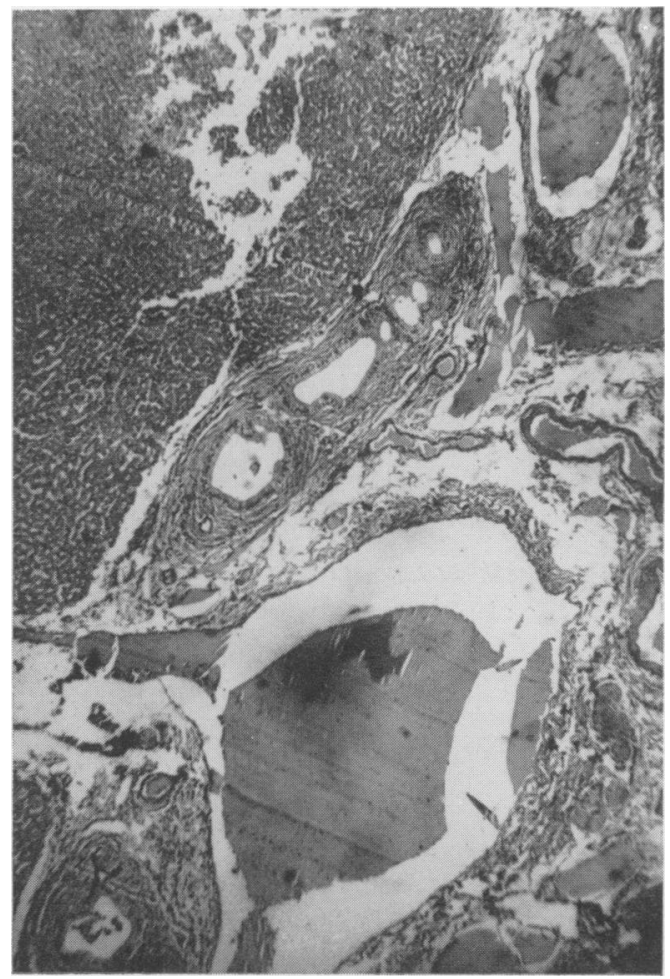

Fig. 3. Photomicrograph of accessory lobe of liver (H and $E \times 100$ ).

TABLE 1. Summary of the reported cases (all female) of accessory lobe of the liver

\begin{tabular}{|c|c|c|c|c|c|}
\hline Reference & $\begin{array}{c}\text { Age } \\
\text { (years) }\end{array}$ & Pre-operative diagnosis & $\begin{array}{l}\text { Causes for } \\
\text { symptoms }\end{array}$ & $\begin{array}{c}\text { Size of } \\
\text { lobe }(\mathrm{cm})\end{array}$ & Pathology \\
\hline $\begin{array}{l}\text { Fisher (cited by Cullen, } \\
\text { (1925) }\end{array}$ & 45 & Appendicitis & Torsion & $6 \times 8 \times 3$ & $\begin{array}{l}\text { Normal and fibrous tissue } \\
\text { with haemorrhagic areas }\end{array}$ \\
\hline Lottee and Madier (1960) & 75 & Cholecystitis/perforated ulcer & Torsion & Not stated & Haemorrhagic necrosis \\
\hline Watson and Lee (1964) & 56 & Not stated & Torsion & Length 4 & Necrosis \\
\hline $\begin{array}{l}\text { Levi, Creque and Cinque } \\
\text { (1969) }\end{array}$ & 23 & $\begin{array}{l}\text { Tubo-ovarian/appendicular } \\
\text { abscess }\end{array}$ & Torsion & Diameter 23 & Necrosis \\
\hline Llorente and Dardik (1971) & 74 & Retroperitoneal tumour & $\begin{array}{l}\text { Traction/ } \\
\text { compression }\end{array}$ & $13 \times 19 \times 9$ & Post-necrotic cirrhosis \\
\hline $\begin{array}{l}\text { Omanik and Jablonsky } \\
(1972)\end{array}$ & 29 & Mesenteric cyst & Torsion & $13 \times 12 \times 7$ & $\begin{array}{l}\text { Steatosis and haemorrhagic } \\
\text { infarction }\end{array}$ \\
\hline $\begin{array}{l}\text { Pujari and Deodhare } \\
\text { (present report) }\end{array}$ & 32 & Exploratory laparatomy & Torsion & $5 \times 4 \times 2$ & $\begin{array}{l}\text { Dilatation, and congestion } \\
\text { of portal tracts and central } \\
\text { veins }\end{array}$ \\
\hline
\end{tabular}


of the hepatic anlage (Fraser, 1952) or by further branching of the foregut diverticulum (Ashby, 1969).

Accessory lobes may be attached to the liver by a pedicle of the liver tissue or by a mesentery (Johnstone, 1965). For the accessory lobe to be viable it should have the hepatic artery, hepatic vein, portal vein and bile duct, which usually communicate through the liver, but occasionally may have extrahepatic connection as in the present case.

All reported cases of this phenomenon, and their symptoms, are summarized in Table 1.

Late presentation is due to gradual worsening of the circulation in the lobe. All the six cases reported were diagnosed at operation. Pre-operative diagnosis can be made by using one or more techniques of pneumoperitoneum, percutaneous hepatic cholangiography, splenic portography, regional arteriography, coelioscopy and scintillation scanning (Omanik and Jablonsky, 1972; Llorente and Dardik, 1971).
References

AshBy, E.C. (1969) Accessory liver lobe attached to the gall bladder. British Journal of Surgery, 56, 311.

Fisher, W., cited by Cullen, T.S. (1925) Accessory lobes of the liver, an accessory hepatic lobe springing from the surface of the gall bladder. Archives of Surgery, 11, 718.

Fraser, C.G. (1952) Accessory lobes of the liver. Annals of Surgery, 135, 127.

JoHnstone, G. (1965) Accessory lobe of liver presenting음 through a congenital deficiency of anterior abdominal $\frac{\omega}{5}$ wall. Archives of Disease in Childhood, 40, 541.

Levi, M.N., CReQue, L. \& Cinque, S. (1969) Accessory lobe of liver presenting symptoms of pelvic tumor. New Yorkes State Journal of Medicine, 69, 1334.

LloRENTE, J. \& DARDIK, H. (1971) Symptomatic accessory? lobe of liver associated with absence of the left lobe. $\overrightarrow{\vec{H}}$ Archives of Surgery, 102, 221.

LOTTEE, J. \& MADIER, G. (1960) Infarction caused by torsion of accessory lobe of liver. Surgery cure. Presse Médicale, $68,838$.

MCGregor, A.L. (1950) Synopsis of Surgical Anatomy, ir 8th ed., p. 418. John Wright: Bristol. OMANIK, S. \& JABLONSKy, I. (1972) Pedunculated accessory
hepatic lobe. Archives of Surgery, 105, 792.

WATSON, J.R. \& LEE, R.E. (1964) Accessory lobe of liver with N infarction. Archives of Surgery, 88, 490.

\section{Chronic hepatitis in polymyalgia rheumatica}

\author{
K. THOMPSON \\ M.A., M.B., B.Ch.
}

\author{
P. F. ROBERTS \\ M.B., M.R.C.P., M.R.C.Path.
}

Norfolk and Norwich Hospital, Norwich

\begin{abstract}
Summary
A review of the literature relating hepatic abnormalities with the giant cell arteritis, polymyalgia rheumatica syndrome is presented. A case of polymyalgia rheumatica with biochemical and histological abnormalities of the liver is described. It is suggested that a more detailed investigation of liver function should be made in patients with this syndrome where reasonably indicated.
\end{abstract}

\section{Introduction}

RECENTLY, attention has been focused on the association between polymyalgia rheumatica, giant cell arteritis and an elevated serum alkaline phosphatase with, or without, other evidence of hepatic dysfunction (Hall and Hargreaves, 1972; Glick, 1972; Dickson et al., 1973; Long and James, 1974). These findings have raised the possibility of an

Correspondence: Dr P. F. Roberts, Consultant Histopathologist, Norfolk and Norwich Hospital, Norwich NR1 3SR. association between liver disease and these two disorders. Long and James (1974) reported findingo granulomatous hepatitis in a single case of polymyalgia rheumatica. A case with different histopathological changes in the liver is now reported.

\section{Case report}

A 77-year-old woman with a long history of은 psoriasis, presented 8 years ago with malaise and 7 severe pain in the muscles of the neck, back and proximal limb muscles. On examination, these muscles were tender to palpation and there was noevidence of psoriatic arthropathy. X-rays of the joints and chest were normal, the haemoglobin was $\omega$ $11 \mathrm{~g} / 100 \mathrm{ml}$ and the ESR $100 \mathrm{~mm}$ in $1 \mathrm{hr}$. Serological tests for gout and rheumatoid arthritis wereo negative. A diagnosis of polymyalgia rheumatica was $ळ$ made. The symptoms abated with oral prednisone ${ }^{+}$ therapy but the ESR remained elevated. Over the next 6 years she remained well apart from exacer- $\frac{\text { Pे }}{\mathbb{D}}$ bations of the disease when steroid withdrawal was $\stackrel{P}{\mathcal{P}}$ 